\title{
Structure, Hierarchy and Kin. An Ethnography of the Old Market in Puerto Princesa, Palawan, Philippines
}

\author{
Bryan W. Rich \\ Palawan Studies Center, Palawan State University, Puerto Princesa, Philippines \\ Email: bryan.w.rich@gmail.com
}

How to cite this paper: Rich, B.W. (2017) Structure, Hierarchy and Kin. An Ethnography of the Old Market in Puerto Princesa, Palawan, Philippines. Open Journal of Social Sciences, 5, 113-124. https://doi.org/10.4236/jss.2017.56010

Received: April 18, 2017

Accepted: June 13, 2017

Published: June 16, 2017

Copyright $\odot 2017$ by author and Scientific Research Publishing Inc. This work is licensed under the Creative Commons Attribution International License (CC BY 4.0).

http://creativecommons.org/licenses/by/4.0/ (c) (i) Open Access

\begin{abstract}
Every day, thousands of customers patronize hundreds of vendors at the Old Market in Puerto Princesa, seeking the highest quality products at the most affordable price. It is a "buyer's market" as the variety of available products is limited to mostly locally produced goods. Why does a customer patronize one vender rather than another? Do social relationships influence this decision? Or, is price king? Does the relationship between customer and employee affect the vendor's success? This paper attempts to shed light on the kinship ties and social stratification between vendors, customers and employees and its effects, if any, on the market's economic success. After more than 6 months of participant observations, my findings show that the fictive kinship ties which develop between the regular customer and vendor, and the social stratification between customer and employee provide a structured functionalism to support the overarching economic theme of the public market.
\end{abstract}

\section{Keywords}

Kinship, Commodity Exchange, Hierarchy, Gender, Stratification

\section{Introduction}

Of the more than 7100 islands that make up the Philippines, Palawan has earned a reputation among local and international tourists. Known domestically as the "last frontier" and making last year's Conde Nast Traveler's list of "best islands in the world" for its unmolested white sand beaches and Subterranean Underground River, Palawan's tourism industry is bustling. Its bucolic splendor aside, the capital of Puerto Princesa is very much like other small cities in the archipelago. The 255,000 Palawenos who call the city their home go about their daily routine, with many converging at some point during the week at the Old Market 
(Palawan News 2016) [1].

Everyday thousands of customers patronize more than 350 vendors for their daily needs. Since the 1960s, the city's Old Market has been the central shopping district for most of its residents. Customers navigate the narrow alleyways, pivoting along the way to inspect the quality and price of a vendor's items. Local restaurant owners also patronize the market, sometimes making a trip in the morning and returning in the afternoon for the best selection. Fresh seafood is also boxed and shipped hourly to the beach resorts in El Nido or trucked to the airport to be flown to Manila.

Local meats, fowl, fish, rice and produce arrive daily via the ubiquitous Filipino lorry, the Jeepney, from either the nearby port or from out of town (see Figure 1). These products are accompanied by imported items popular with the Filipino palette, coming from different provinces in Luzon, Visayas and Mindanao. A small number of international imports can be found too, including apples and grapes from the US, oranges and garlic from China, Soybeans from Canada and wheat flour from Turkey. Sundries and household items can also be had, making the market a one-stop-shop for many.

Most produce vendors sell accoutrements to complement their primary products. Meal size packs of spices, soy sauce, vinegar and tomato paste are strategically on display around many stalls. In addition to pre-packaged items, some vendors make their own bagged servings from bulk purchases such as salt, pepper, margarine and corn starch. If a volume or weight is not visibly available, some vendors can fulfill customers' requests for custom quantities. These serving sizes serve two purposes. First, it's space. Many families have limited kitchen and food preparation space. Some families share kitchen space with their extended family or neighbors, or have their kitchen space outside which is more likely to be exposed to the harsh tropical weather. Second, it's money. Many families in town do not own a refrigerator due to its purchase price and high cost of electricity. Finally, many families are small business owners or have intermittent work, relying on a day's work and a day's pay, so they purchase only what they need for each meal.

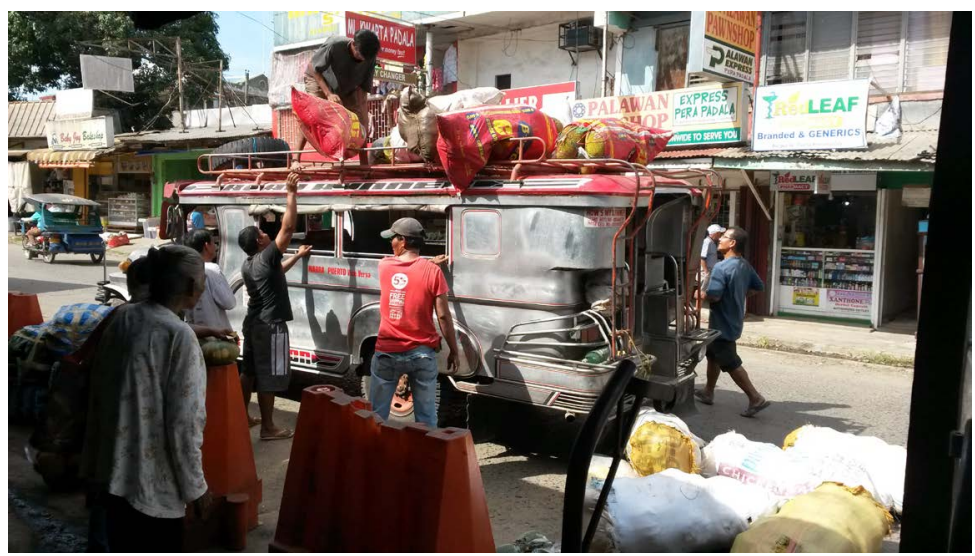

Figure 1. Original photograph by author. A regular scene outside the market. The Jeepney arrives with fresh produce and is unloaded. 
A quick stroll through the market and one observes many vendors selling similar items. I counted more than 30 rice vendors and more than 70 vegetable vendors. A more careful observation will reveal that most vendors have similar prices. What attracts a customer to a specific vendor? How do price and quality compare to the personal relationship between vendor and customer? This paper attempts to shed more light on the underlying social behavior exhibited by customers, vendors and employees that support the overt economic success of the public market.

\section{Methodology}

My ethnography began in July 2016 and my observations lasted until February 2017. My sister-in-law, Leanora, who had been working at the market for more than 25 years, first assisting her mom selling flowers, and now as a manicurist, introduced me to several vendors who agreed to allow me to observe their daily operations. Her introductions paved the way for me to build rapport with the vendors and to observe their most personal interactions, both financial and personal. Depending on the configuration and size of each stall, I either observed from behind the counter, near the owner, or from just outside the stall, but close enough to understand each transaction.

I approached this study with an interpretive method to qualitatively and subjectively analyze each observation setting and the information and social behavior divulged by my informants (the owner and employees) and customers. I focused my attention on the interactions and relationships between the following: 1) vendor and employee; 2) vendor and customer; 3 ) employee and customer; and, 4) the interactions between employees. Some vendors also patronize each other. There are a small number of vendors who purchase large quantities of products wholesale and provide discounted prices to the smaller vendors in the market.

This research reflects my observations for more than six months of five different vendors: rice; animal feed; produce; and, fish. I rotated vendors every few weeks, observing for 4 to 6 hours per day, 4 to 5 days a week.

\section{Kinship}

Kinship provides the fundamental structure for consanguineal and fictive groups (Sahlins 2013) [2]. It creates social rules and boundaries for marriage and procreation, cooperation, exchange, reciprocation and obligations. From one's role and status in the home to expectations outside the home in social and financial situations, most of one's life is structured according to one's kin.

Family ties were strong in the market. Most vendors I patronized, in addition to my informants, had at least one immediate family member assisting in some capacity. Extended kinship ties were strong, too. Many vendors, including some of my informants, had cousins, aunts, uncles, nieces and nephews who owned and operated other stalls in the market. They purchased from one another and provided social support. Fictive kin ties also strengthen economic and social ties.

Whereas economists would study a public market for its deliberate commodi- 
fied exchange of money for goods and services, supply and demand, profit and loss, the social scientist observes the market for what the exchange of money symbolizes, its personal relationships, money's symbolism and is shaped by its social relationships (Baker 1992) [3]. This ethnography explores the embedded personal relationships vis a-vis its structural and functional roles of gender, social hierarchy, as determinants of kinship ties.

The anthropological analysis of social relationships in market economies dates back nearly a century when Bronislaw Malinowski and Marcel Mauss introduced readers to the motivations for gifts and reciprocal exchange ${ }^{1}$. More recently, in his book Gifts and Commodities, Christopher Gregory proposed that the commodity exchange is a quantitative relationship with few social consequences while the gift exchange is qualitative relationship that has lasting obligations (Gregory 1982) [4]. Although Gregory contrasted the capitalist market (commodity exchange) with a reciprocal exchange of gifts between kin, I use his theoretical approach to shed light on the two main purchasing actors in the market, the occasional customer and the regular customer. Gregory presented the following traits to delineate between the commodity and gift exchange.

\section{My Informants ${ }^{2}$}

Cousins Nina and Ronny operate a busy vegetable stall with seven employees ranging in age from 15 - 24 years old. All their employees are "stay-in". They arrive every morning at $5 \mathrm{am}$ and depart about $7 \mathrm{pm}$ each evening. They have been vendors at the Old Market for 10 years and have established a successful business attracting regular customers with good quality produce and competitive prices. They also buy wholesale directly from suppliers and supply about 14 other vendors at the market with products, including some who operate at the carinderia, the market's open air food court.

Sisters Mary and Gigi began working at their mom's animal feed stall in 1977. Today, their brother owns the stall, which is one of the few dedicated to providing feed for pigs, chickens, cats and dogs. Despite its size and near constant flow of customers, they only employee one full-time boy to help with the heavy lifting of feed that is delivered many times during the day.

Jerry, brother of Mary and Gigi, and his wife operate a rice stall nearby. They have operated at the market for 12 years. As there are more than 30 rice stalls in the market with similar prices, most of Jerry's business is selling to other vendors and local restaurants. They employee their nephew who lives with them. When Jerry and his wife are making deliveries, their nephew is left to run the stall.

Nancy, in her 60s, has operated a small fish stall at the market for 30 years. She only sells bangus, or milk fish, the national fish. Of the dozens of varieties of fish available every day, she is only one of 3 vendors who are dedicated bangus

${ }^{1}$ See Bronislaw Malinowski's Argonauts of the Western Pacific (1922) and Marcel Mauss's The Gift (1925).

${ }^{2}$ Names have been changed for privacy. 
vendors. Most of her business is supplying local restaurants and hotels, so whenever she is not assisting a customer, she and her nephew are busy filleting and deboning for the day's orders.

Darwin's produce stall is by far the largest and busiest in the market. He has been working at the market for about 30 years. He began helping his parents by selling corn on the street when he was 12 years old. Not only does he have the largest retail operation, but he is also the largest wholesaler for vendors at the market, local restaurants and resorts. He and his wife have 6 employees dedicated to assisting customers and a few others relegated to receiving deliveries and stocking produce bins. His regular vendor-customers freely walk into the stall, approach his desk and ask for the daily price of a product.

\section{Findings}

I originally embarked on this ethnography to better understand in what way, if any, kinship ties affect how the Old Market functions as a place of business in Puerto Princesa. My observations yielded three sets of findings: 1) the financial and social value of the regular customer; 2) gender roles and hierarchy among employees; and, 3) how age and social stratification affect the employee customer relationship. My findings are not extraordinary or an anomaly, but rather reflective of the role kinship ties and social stratification perform in greater Philippine society.

Product turnover is constant. Shipments of fresh produce and fish arrive hourly to meet customer demand and to replenish products that have perished. Quantities and prices fluctuate for this reason so it is not uncommon to see vendors without advertised prices. Most patrons shop for specific items with a budget so are after the best products at the cheapest price.

This occasional customer will patronize multiple vendors, with three objectives: high quality; lowest price; and, convenience. In the Old Market, this person considers the exchange to be objective, a business transaction of exchanging money for a product. The customer may quickly scan the items for quality, inquire about the price and if both meet expectations, the customer will proceed to make a selection for purchase. Dialogue is short and to the point. For the occasional customer, the act of purchasing items from a vendor is characteristic of a commodity exchange. There is very little reciprocity and dependency. What does exist can be considered simplified commodification. The reciprocation and dependency are based upon supply and demand.

The customer wields very little trust during this anonymous transaction. He will carefully eye the scale as the products are weighed, mentally calculating the sum of multiple items and will meticulously count any change received, sure not to be taken advantage of. There is no social motivation for the customer to return, but there may be a financial incentive to re-patronize.

There is also the customer who will sacrifice one of the three motivations above and consistently patronizes one vendor. The suki (su-key), or regular customer, has built a relationship with the vendor for several reasons. Sometimes it 
is the best price or quality which introduces the customer to the vendor. Some know each other through mutual friends or from outside the market and feel it is a social obligation to patronize that vendor. Whatever the reason may be, economic or social, they have developed fictive kin ties.

The evolution of the suki relationship mirrors how other relationships develop. With time, attention and trust, the customer may begin to go out of his or her way to patronize the familiar face. However, since this is a place of business where the primary motivation is to buy and sell, the most prevalent difference is that this relationship begins as an impersonal quantitative relationship between objects (see Table 1).

The regular customer not only provides most of the daily sales, but much of the daily socialization for the owner and employees. Some customers have been loyal patrons for years based on a mutualistic relationship of financial and social reciprocity. There are no explicit rules as to how or when one becomes a suki, but forms per its rapport. It could take shape after a week of daily exchange, or after a month of weekly exchanges.

Two informants offered slightly differing reasons as to what attracts a regular customer. Ronny proffered the most important qualities were 1) price, 2) quality and 3) attitude. Jobelle, daughter of Jerry, suggested trust as most important, followed by the quality of product and being treated like family.

There are two primary financial benefits of being a regular customer, or suki: 1) tawad, or discount; and, 2) hulugan, or installments. The discount is usually offered to customers and the installments are usually offered to vendors who patronize the larger vendors for wholesale prices. After a financial relationship has been established between vendor and customer, a social bond forms reinforcing the financial exchange, which reciprocates with stronger fictive ties. The financial bond reinforces the social bond, creating cyclical support.

At Darwin's stall, customers occasionally ask him directly for the price of an item, bypassing the employee directly behind the counter. This tactic is used to "show face" to Darwin to procure a discount. Another tactic is when Darwin quotes a price, the customer repeats the quoted price back to Darwin with a look of uncertainty. Depending on the customer and quantity, Darwin may reply instantly with a slight discount to make the sale. Occasionally, I observed regular customers haggling over the price with Darwin, unusual for the Market.

Table 1. Gregory's contrast of commodity and gift exchange from gifts and commodities.

\begin{tabular}{cc}
\hline Commodity Exchange & Gift Exchange \\
\hline Immediate exchange & Delayed exchange \\
Alienable goods & Inalienable goods \\
Actors independent & Actors dependent \\
Quantitative relationship & Qualitative relationship \\
Between objects & Between people \\
\hline
\end{tabular}


More often, it is Darwin who initiates the discount. When the employee hands Darwin the payment to receive change, he may look up and notice the customer and deduct a small amount from the total, usually rounding down. I found this to be strategic. He does this speaking just loud enough that the customer making the purchase can hear, and so can the other customers shopping.

Employee: 156, kuya. The employee hands Darwin two 100 peso notes.

Darwin: 150, 50. Darwin states the new price and the change he will give.

The suki relationship also benefits the customer with installments. Ronny and Nina offer hulugan to the vendors he supplies by crediting them in the morning or the day before, then collecting the next afternoon. This financial situation is very common among vendors and local restaurant owners. For vendors, it keeps the Market functioning. Most stalls are smaller, selling only few items with a limited quantity. For these vendors, it would be cost prohibitive to purchase, for example, 10 kilos of tomatoes, up front. For customers, particularly restaurant owners, they will drop a shopping list off with Ronny, continue with their shopping, and pick the order up shortly thereafter. The customer may return later in the day to pay a portion of what is owed, or return the following day with full payment.

To the contrary, there may be no financial benefit to being a suki, but for only social reasons. It may be based strictly on rapport, the vendor may be friendly with a pleasing personality, or, as mentioned earlier, the vendor is a friend of a friend. The suki may not be after a discount, but just wants a familiar face at the market when shopping.

There are social benefits to the vendor-suki relationship. As the fictive kinship ties strengthen, so do the degrees of attention and trust. The employees may ask the suki what he or she wants and proactively selects the best quality produce. The relationship is such that the customer trusts the vendor and expects to get the best selection of product. The suki will continue to chat with the owner as trust of the exchange has solidified ties between vendor and customer. The items are weighed and calculated. The final price is told to the suki and any change received is pocketed without counting. The quantified relationship has evolved into a qualitative relationship between people, not objects, as supported by Gregory.

The "commodity exchange" as theorized by Gregory, will always exist in capitalistic economies. The object of the Market will always be to buy and sell goods. However, the success of the Market and its more than 350 vendors will be determined by relationships. The suki breaks down traditional social stratification of power and class with its creation of fictive kin ties. Although a commodity exchange has been historically associated with impersonal capitalist economies, the public market, and specifically the Old Market should be considered an exception to the "rule". The "gift exchange" of the discount given to the customer solidifies the reciprocal social and monetary relationship.

This section focuses on the observations of three of my 5 informants who had multiple employees and how labor is divided among gender roles. In the Philip- 
pines, urban and rural, customer service positions are predominately filled by young women. From the "mom and pop" sari-sari stores and the food stand on the side of the road, to more formal settings including grocery stores and shopping malls, women are the feminine faces of these establishments. Masculine jobs requiring any physical labor will be assigned to men. Walking through the market, it does not take long to recognize the division of labor between men and women. By and large, the stalls that operate with more than two hired employees, non-familial, operate according to culturally prescribed gender roles.

The Market's gendered labor follows structured culture and social rules creating a functional theatre of interdependency. These strict codes of labor foster social cohesion, even in this small setting of the public market, creating status among employees and mechanizes productivity (Durkheim 1933) [5]. Vendors looking for new employees post handprinted signs with "sales lady" or "boy helper". The signs' purpose is for what work is entailed. Its social status is implied (see Figure 2).

Darwin's stall has similar gendered roles. His female employees primarily worked behind the counter assisting customers with occasional cleaning and stocking. His male employees bore the brunt of the physical labor. Yet, his openly gay male employee worked behind the counter with the girls, adhering to the structured gendered roles.

Social stratification is implicit and explicit in the Philippines. The developing country may be considered a classical stratified society based on socioeconomics and purchasing power. Earlier, I wrote about the social stratification between the occasional customer and the vendor, in contrast with the fictive kin ties that develop between the suki and the vendor. Another visible variable of social stratification in the Philippines is age. Like gender, age is an element of kinship structure in the Philippines and transcends social class and rural-urban stratification.

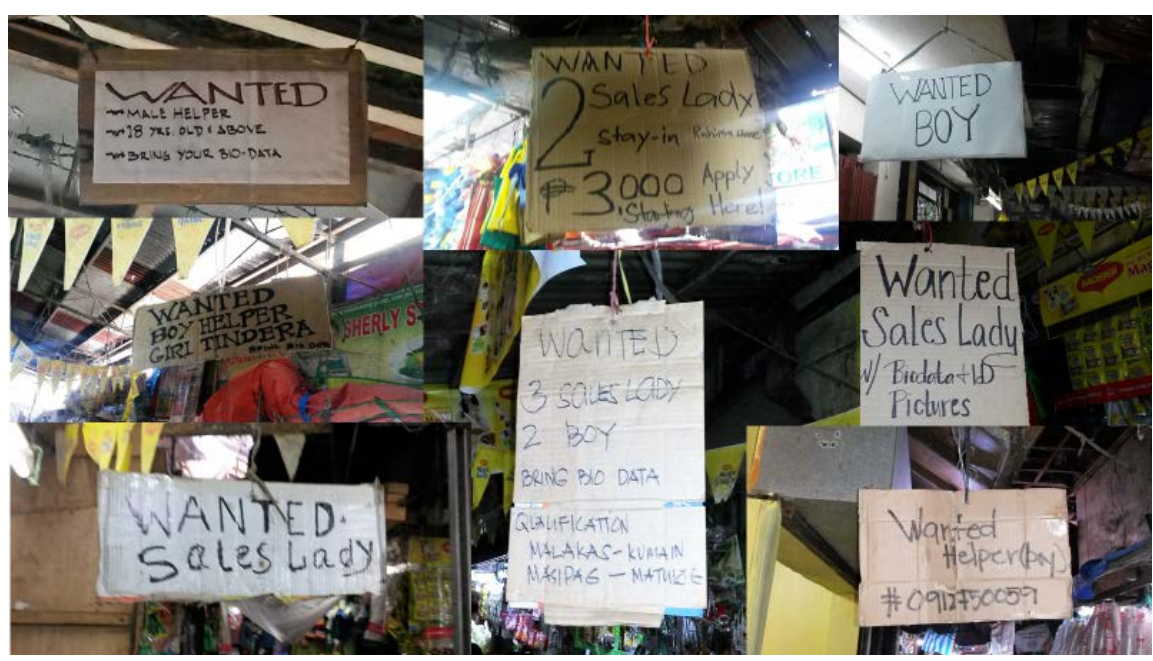

Figure 2. Original photograph by author. "Help Wanted" signs in the market. Translation of the middle sign: strong and diligent eat and sleep. Attrition rates are so high, many signs stay up indefinitely. 
From a young age, children are raised to respect their elders with specific titles and recognition. The most common title is "Po". This is used in all aspects of public and private life. The English equivalent of Sir or Ma'am, it can be used in many situations, including: "thank you Po", "excuse me Po", "yes Po", "no Po". It can also be used as "Po?" as "I didn't understand you, can you please repeat it?". It crosses all social class boundaries and when it comes to age, its usage is usually erred on the side of caution. There are also formal titles, traditionally used to refer to older siblings. "Ate" (ah-tay) is used to refer to older females (traditionally a sister) and "Kuya" to refer to older males (traditionally a brother).

Ate and Kuya can also be used between fictive kin. All the employees I observed addressed their respective employers by Kuya or Ate, which represented a bond, which would otherwise had been unheard of between subordinate and superior. My informants reciprocated, addressing their employees the same. This was interesting because it went against traditional respect or the subordinate-superior relationship, and with age, which was the case most of the time.

What contrasted Ronny and Nina's stall from my other informants was the relationship between the customer and employee. Initially, my observations were leading me to conclude that the relationship between customer and employee was social stratification based on socioeconomic class. As the employee would assist the customer with bagging and counting vegetables, the customer would intentionally not talk to, or avoid making eye contact with, the employee. The customer would also avoid making eye contact when handing payment to the employee, thereby upholding the commodified exchange, as discussed earlier. The frequency of this behavior led me to conclude that the social stratification between customer and employee was based on age.

Ironically, even though the respect of age transcends socioeconomic class, age discrimination for hiring is widespread. Job postings regularly advertise the desired age of the applicant. Although this is more common for customer service positions seeking young women, jobs for physical labor can be applied too.

Perhaps the most powerful stratification in developing and developed societies is economic power. Absent of any personal relationship between customer and vendor, the commodified transaction is objectified by money's symbolic value. Revisiting the gestures of the occasional customer towards the vendor and employee, one more element of social stratification is how the customer presents payment for the purchase.

\section{Discussion}

Despite the Philippines' rapid economic growth in recent decades, kinship ties still dictate social and cultural behavior patterns. I wanted to see if this was true in the traditional public market. I wanted to capture what, if any, effects relationships have on the economic success in the Old Market in Puerto Princesa. My observations revealed that fictive relationships between vendors, customers and employees create a functional environment for continued economic success 
in the market, and that this success was reciprocal.

The Old Market thrives on the relationships and fictive kinship ties. A vendor's success, financial and social, is dependent upon the gift exchange. Revisiting Gregory's theory of Gifts and Commodities, the exchange dramatically shifts when the relationship changes from commodity to gift. In other words, when fictive kin ties are produced between two groups, the previously perceived social class rules become nonexistent. Many of my observations between customer and employee crossed lines of social class and age. Perhaps there were many when both applied. The primary exception to this was among suki as I touched upon earlier. A fictive relationship dramatically changes the dynamics of the financial exchange.

There were a number of reoccurring observations I had not anticipated upon commencing my research. Although I was expecting to observe some degree of social stratification between vendors and their employees, I was not expecting there to be a practiced hierarchy strictly among the employees. When analyzing the gendered labor roles of my informants and their employees, it was interesting to observe how gay and lesbian staffs are assigned duties. Finally, and most interesting, were my observations of how the symbolic value of money created, what I call, transactional devaluation.

A reoccurring observation that I had not expected was a sub-stratification among some employees. Observations at Mary and Gigi's and at Ronny and Nina's stall yielded a delegation of duties, still dependent upon gender, but also upon one's status as a new or old employee. The newer employees bore the brunt of physical labor, while the long-term employees could delegate tasks and were more likely to be trusted with handling cash. Gender roles were very overt. The female employees were much more likely to cater to the customers, while the male employees were relegated to more physical labor such as handling deliveries and stocking the products. This behavior is reminiscient of kinship ties at the home. Children have duties delegated to them by their parents based on sex and age. This "rule" remains even as the children become adults and live in extended family households. Grandparents, parents, uncles and aunts, nieces and nephews will have specific duties based upon their age and sex.

One unanticipated observation occurred when one of my informants hired two new employees on the spot. Two teenage boys approached Ronny and Nina's stall, replying to a sign hanging in front of their stall. One was smaller stature, with a fit physique, while the other boy was taller, slim, wore a plastic head band to keep his hair away from his face, fingernails painted and eyeliner. Neither had work experience, but Nina jokingly asked the flamboyant boy if he had ever worked in a hair salon. Both agreed to accept her offer: 3000 pesos per month plus full room and board, referred to as a "stay-in". Each immediately began their new jobs. The smaller "straight" male was relegated to peeling onions, accepting new shipments and weighing products and stocking. The "gay" employee began to assist customers with the other two sales ladies.

It was socially acceptable to give gay men the labor roles of women, or, cus- 
tomer service. For lesbians, it was socially acceptable and expected for them to take on "male" tasks of heavy lifting and other physical requirements. This reflects the sexual progressiveness of the Philippines, and in retrospect, is quite common. Despite its public persona as a strict Catholic country, gays and lesbians enjoy respect and equality on par with the most progressive European countries.

My observations of the symbolic value of money between subjects focuses on the cultural and structural perspective of money at the micro-level, as described by Baker and Jimerson (1992) [3], as an object in interpersonal relationships and communication. An existential observation of the social hierarchy in the market was the symbolic value placed on money and more specifically the physical exchange of money from customer to employee.

The actions by the customer further devalue the transaction, by which I call transactional devaluation. One of my more interesting observations over the last six months was how the customer's interpretation of money changed during the financial transaction. I found once the decision was made to exchange the money for a product, its symbolic value significantly diminished. This was revealed by the actions of the customer as he or she withdrew the money from a wallet or purse and presented it to the vendor or employee. More often, no eye contact was made during the transaction as the customer handed the money in a disheveled state. I draw this conclusion from numerous observations beyond the market.

These reoccurring observations give new meaning to the term purchasing power. However, rather than the semiotic value of money transferring or exchanged from one party to another, the purchasing power is a consolidated, non-reciprocal action by which the power is transferred to the item for which the money is exchanged.

\section{Conclusions}

The Old Market attracts customers from all economic backgrounds. What remains constant is that price is king. Of the thousands of customers who traverse the market every day, many seek the best product at the lowest price to stretch their pesos as far as possible. However, as important as price is, it is not the only factor for patronizing one vendor rather than another. If it were, the few vendors with the lowest prices would reap all the business. This is obviously not the case.

Even in capitalist markets, such as the Philippines, it is not unheard of, or rather, it can be expected that an economic exchange is more likely to happen between two parties with a stronger relationship even if there is less financial gain by either or both parties.

\section{References}

[1] Santos, C. (2016) Census: Puerto Princesa Records 255K Population; Brgy San Pedro "Most Populous". Palawan News.

http://palawan-news.com/census-puerto-princesa-records-255k-population-brgy-sa n-pedro-populous/ 
[2] Sahlins, M. (1972) Stone Age Economics. Aldine \& Atherton, Inc., Chicago.

[3] Baker, W. and Jimerson, J. (1992) The Sociology of Money. The American Behavioral Scientist, 35, 678-693. https://doi.org/10.1177/0002764292035006005

[4] Gregory, C.A. (1982) Gifts and Commodities. Hau Books, Chicago.

[5] Durkheim, E. and Simpson, G. (1933) The Division of Labor in Society. The Free Press, Glencoe, Illinois.

Submit or recommend next manuscript to SCIRP and we will provide best service for you:

Accepting pre-submission inquiries through Email, Facebook, LinkedIn, Twitter, etc. A wide selection of journals (inclusive of 9 subjects, more than 200 journals)

Providing 24-hour high-quality service

User-friendly online submission system

Fair and swift peer-review system

Efficient typesetting and proofreading procedure

Display of the result of downloads and visits, as well as the number of cited articles Maximum dissemination of your research work

Submit your manuscript at: http://papersubmission.scirp.org/

Or contact jss@scirp.org 